\title{
SCHIZOTHYRIOMA PTARMICAE (HELOTIALES, ASCOMYCOTA), A RARE EUROPEAN FUNGUS NEWLY FOUND IN POLAND
}

\author{
IWONA ADAMSKA \\ Department of Plant Pathology, University of Agriculture \\ Słowackiego 17, 71-434 Szczecin, Poland \\ e-mail: iwonaadamska@interia.pl
}

(Received: April 14, 2003. Accepted: August 11, 2003)

\begin{abstract}
The morphological properties of Schizothyrioma ptarmicae (Helotiales, Ascomycota), a fungus known from a single locality in Poland and infrequently reported from Europe, are described and illustrated. Schizothyrioma ptarmicae is a parasite of leaves of Achillea ptarmica. It has been found in the Myrico-Saliceto auritae and Cirsio-Polygonetum plant associations of the Słowiński National Park. Additionally, the properties of the specimens of S. ptarmicae collected were compared with those of S. aterridium, the only other member of the genus Schyzothyrioma.
\end{abstract}

KEY WORDS: Schizothyrioma ptarmicae, occurrence, Słowiński National Park.

\section{INTRODUCTION}

The Słowiński National Park (SNP; $54^{\circ} 38^{\prime}-54^{\circ} 46^{\prime} \mathrm{N}$, $\left.17^{\circ} 03^{\prime}-17^{\circ} 33 \mathrm{E}\right)$ is a unique area of Poland, housing over 830 vascular plant species (Piotrowska 1991). About 30\% of these species have a narrow distribution range, occurring in single sites or are interesting due to their ecological properties. Thus, SNP is an exceptionally valuable area to study the biodiversity of different organisms.

Among the 310 species of fungus-like and fungi belonging to 79 genera found in SNP, Schizothyrioma ptarmicae (Desm.) von Höhnel (Helotiales, Ascomycota), a taxon earlier not recorded in Poland and infrequently reported from Europe (Holm 1971), was listed (Adamska et al. 1999). However, Adamska et al. (1999) neither characterized nor illustrated the morphological properties of the specimens collected of this fungus. Therefore, the main aim of this paper was to describe and illustrate $S$. ptarmicae found in Poland. Additionally, the properties of the found specimens were compared with those of the only other species of the genus Schizothyrioma, i.e., S. aterridium (Karst.) L. Holm.

\section{MATERIALS AND METHODS}

Infected leaves of Achillea ptarmica L. were collected in the Myrico-Saliceto auritae (Allg. 1922) R. Tx. et Pass. 1961 and Cirsio-Polygonetum R. Tx. 1951 plant associations of SNP. The plant associations were determined according to Matuszkiewicz (1984). In the laboratory, the leaves were dried between sheets of blotting-paper. Subsequ- ently, the leaves were observed both with naked eye and under an Olympus SZx9 dissecting microscope. Using a safety razor, thin cuttings were taken from transverse sections of the present fungal fruit bodies and the leaves of its host. The cuttings were placed in drops of lactic acid, polyvinyl alcohol/lactic acid/glycerol (PVLG; Koske and Tessier 1983), and a mixture of PVLG and Melzer's reagent $(1: 1 \mathrm{v} / \mathrm{v})$. The cuttings were examined under an Axiolab Zeiss compound microscope. Measurements of the fungal structures were made using an ocular micrometer. Microphotographs were captured in a Sony 3CCD colour camera coupled to an Olympus BX 50 compound microscope equipped with differential interference contrast optics. Colour names are from Kornerup and Wanscher (1983). Nomenclature of plants is according to Mirek et al. (1985). Dried leaves of A. ptarmica hosting $S$. ptarmicae and microscopic specimens of this fungus, mounted in PVLG on slides, are deposited in the Department of Plant Pathology (DPP), University of Agriculture, Szczecin, Poland.

The chemical properties of soil samples, collected from under the plant associations where $S$. ptarmicae occurred, were determined in the Voivodeship Chemical and Agricultural Station in Szczecin.

\section{DESCRIPTIONS OF THE SPECIES AND DISCUSSION}

Schizothyriomma ptarmicae (Desm.) von Höhnel (Figs 1-6)

Lesions on leaves randomly distributed, black, shining, oblong, slightly raised, 0.2-0.6 × 0.4-0.8 mm (Figs 1 and 2). Apothecia sessile, $0.5-1.0 \times 0.5 \mathrm{~mm}$, present on the upper 

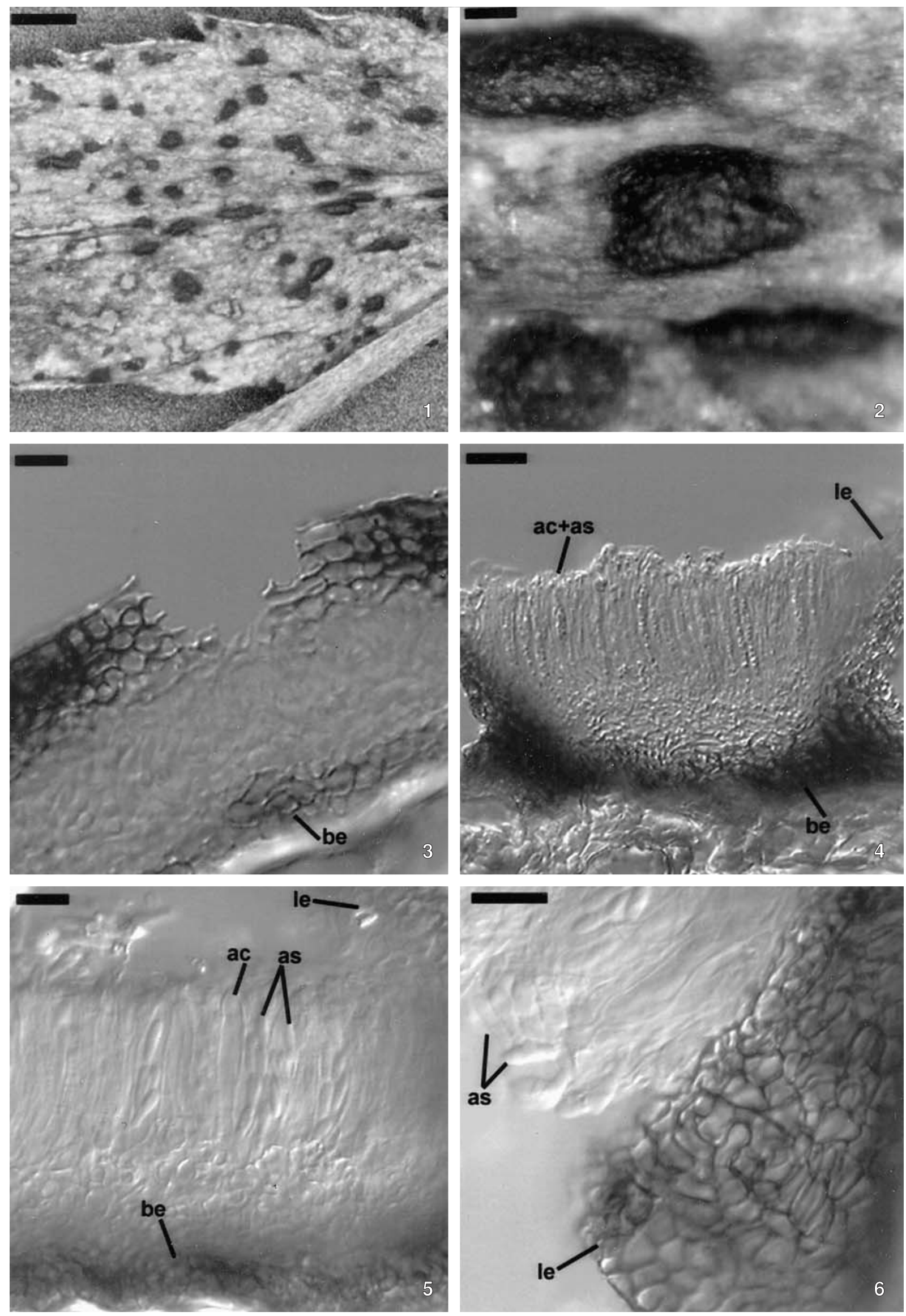

Figs 1-6. Macro- and microscopic properties of Schizothyrioma ptarnicae. 1 and 2. Leaves of Achillea ptarmica with apothecia S. ptarmicae. 3. Immature apothecium and its bottom excipulum (be). 4. Asci with ascospores (ac+as), lateral exipulum (le), and bottom excipulum (be). 5. Asci with ascospores (ac+as), lateral excipulum (le), and bottom excipulum (be). 6. Polyhedral lateral excipulum (le) and ascospores (as). Figs 1 and 2, bright field microscopy; Figs 3-6, differential interference contrast. Figs 3-5, specimens in PVLG + Melzer's reagent; Fig. 6, specimen in PVLG. Bars: Fig. $1=1$ mm; Fig. $2=0.1$ mm; Figs 3,5 and $6=10 \mu \mathrm{m}$; Fig. $4=20 \mu \mathrm{m}$. 
and lower surfaces of leaves (Figs 1-6). Lateral and bottom excipulum composed of polyhedral cells, 5.0-10.0 × 5.0$-12.5 \mu \mathrm{m}$ (Figs 3-6). Lateral excipulum dark brown (7F5), (17.5-) 25.0-37.5 (-50.0) $\mu \mathrm{m}$ thick, bottom excipulum fawn brown (7E4), (20.0-) 25.0-32.5 (-37.5) $\mu \mathrm{m}$ thick. Asci clavate, $6.0-7.5 \times 50.0-62.5 \mu \mathrm{m}$, mainly with four didymospores, occasionally with 2-6; greater cell 7.5-10.0 $\times 2.2-5.0 \mu \mathrm{m}$, smaller cell 2.5-5.0 × 2.5-5.0 $\mu \mathrm{m}$ (Figs 4-6). Neither asci nor spores stain in Melzer's reagent (Figs 4-6).

\section{Collection examined}

Poland. Słowiński National Park ( $\left.54^{\circ} 45^{\prime} \mathrm{N}, 17^{\circ} 26^{\prime} \mathrm{E}\right)$, associated with leaves of A. ptarmica, 18 Sept. 1996 and 24 Sept. 1998, Błaszkowski J., 2418-2423 (DPP).

\section{Distribution and habitat}

In Poland. On leaves of A. ptarmica growing in the Myrico-Salicetum auritae and Cirsio-Polygonetum plant associations of the Słowiński National Park.

The soil chemical and physical properties of the site harbouring the Cirsio-Polygonetum plant association with $A$. ptarmica hosting S. ptarmicae were: $\mathrm{pH}$ (in $\mathrm{H}_{2} \mathrm{O}$ ), 4.4-5.5; $\mathrm{N}-\mathrm{NO}_{3}\left(\mathrm{mg} \mathrm{L}^{-1}\right), 3.0-5.0$; P, 26.0-108.0; K, 13.0-64.0; Ca, 476.0-595.0; Mg, 38.0-79.0; Cl, 33.0-87.0; Na, 38.01-14.0; $\mathrm{KCl}, 70.0-240.0$; org. C (\%), 1.83-4.50; bulk density (kg L-1), $0.75-1.50$.

The properties of the soil from under the Cirsio-Polygonetum plant association where A. ptarmica affected by $S$. ptarmicae grew were: $\mathrm{pH}, 3.5-3.9 ; \mathrm{N}-\mathrm{NO}_{3}, 3.0-4.1 ; \mathrm{P}$, 31.0-85.0; K, 10.0-25.0; Ca, 289.0-374.0; Mg, 43.0-52.0; $\mathrm{Cl}, 31.0-63.0 ; \mathrm{Na}, 36.0-80.0 ; \mathrm{KCl}, 150.0-380.0$; org. $\mathrm{C}$, 1.0-9.12; bulk density $0.55-1.40$.

No other reports exist on the occurrence of S. ptarmicae in Poland.

\section{General distribution}

Despite A. ptarmica, the only plant host of $S$. ptarmicae, occurs commonly in Europe, Asia and North America, this fungus was so far found only in Europe (Holm 1971). Literature data indicate that $S$. ptarmicae is an exceptionally infrequently occurring fungus in Europe and Poland is the fifth country in which it was recorded. The specimens of $S$. ptarmicae examined by Holm (1971) came from France, Germany, and Holland. Moore (1959) listed S. ptarmicae among British parasitic fungi.

\section{DISCUSSION}

The genus Schizothyrioma comprises two species, $S$. aterridium and $S$. ptarmicae, the latter fungus characterized here. These fungi are hosted only by A. ptarmica and are superficially indistinguishable. The main properties separating the two fungi are the number of spores in an ascus, size of ascospores, and the reactivity of asci in mountants containing iodine. Whereas $S$. ptarmicae forms asci with 2-6 spores (Figs 4-6), those of $S$. aterridium usually contain eight ascospores, occasionally six (Holm 1971). Additionally, the ascospores of the former species (Figs 4-6) are ca. 2-fold wider than those of the latter fungus. Finally, no structure of $S$. ptarmicae stains in iodine-based mountants (Figs 3-5), which in S. aterridium takes place and reveals an apical ring (Holm 1971). In contrast, the ascus of $S$. ptarmicae entirely lacks an apical ring. According to Holm (1971), the differences presented above suggest that $S$. ptarmicae is a more advanced fungus and was derived from the 8-spored, J+ ascus of $S$. aterridium.

As mycological literature shows, the position of $S$. ptarmicae in the classification system of cup fungi has changed. This fungus was included in the families Euphiacidieae, Hypodermataceae, and Phiacidiaceae (Holm 1971). According to Holm (1971), the biology, morphological properties of the fruit body, and the characters of spores, asci, and paraphyses of S. ptarmicae suggest it to be a member of the family Pseudopezizoideae. In Ainsworth and Bisby's Dictionary of the Fungi (Kirk et al. 2001), the genus Schizothyrioma belongs to the family Dermateaceae.

\section{ACKNOWLEDGMENT}

This study was supported in part by The State Committee for Scientific Research (KBN), grant no. 3.P04G. 017.23.

\section{LITERATURE CITED}

ADAMSKA I., MADEJ T., CZERNIAWSKA B., BŁASZKOWSKI J. 1999. Parasitic and saprotrophic fungi from Słowiński National Park. Acta Mycol. 34: 97-103.

KIRK P.M., CANNON P.F., DAVID J.C., STALPERS J.A. 2001. Ainsworth \& Bisby's dictionary of the fungi. Ninth Edition. CAB International.

HOLM L. 1971. Taxonomic notes on Ascomycetes. VII. Schizothyrioma Ptarmicae (Desm.) von Höhnel, and ist double. Svens Bot. Tidskif 65: 208-212.

KORNERUP A., WANSCHER J.H. 1983. Methuen handbook of colour. 3rd Ed. E. Methuen and Co., Ltd., London, 252 pp.

KOSKE R.E., TESSIER B. 1983. A convenient, permanent slide mounting medium. Mycol. Soc. Am. Newsl. 34: 59.

MATUSZKIEWICZ W. 1984. Przewodnik do oznaczania zbiorowisk roślinnych Polski. PWN, Warszawa, 298 pp. (in Polish)

MIREK Z., PIĘKOŚ-MIRKOWA H., ZAJĄC A, ZAJĄC M. 1995. Vascular plants of Poland. A Checklist. Polish Botanical Studies, Guidebook 15, Kraków, 303 pp.

MOORE W.C. 1959. British parasitic fungi. A host-parasite index and a guide to British literature on the fungus diseases of cultivated plants. Cambridge University Press, $430 \mathrm{pp}$.

PIOTROWSKA H. 1991. The development of the vegetation in the active deflation hollows of the Łeba Bar (N Poland). Fragm. Flor. et Geobot. 35: 173-215. 